\title{
PENGARUH GAYA KEPEMIMPINAN TERHADAP KINERJA PEGAWAI PADA KANTOR DISTRIK NAVIGASI KELAS I MAKASSAR DITJEN PERHUBUNGAN LAUT
}

\author{
Tamrin Meda ${ }^{* 1}$, Ririn Indraswari ${ }^{2}$ \\ Dosen STMIK Handayani Makassar \\ E-mail : tamrin.samata@gmail.com
}

\begin{abstract}
Abstrak
Penelitian ini bertujuan mengetahui dan menganalisis pengaruh factor gaya kepemimpinan direktif, konsultasi, partisipasi dan delegasi berpengaruh terhadap kinerja pegawai pada Kantor Distrik Navigasi Kelas I Makassar Ditjen Perhubungan Laut. Populasi yang dijadikan sebagai target penelitian ini adalah pihak-pihak yang terkait dengan kinerja pada Kantor Distrik Navigasi Kelas I Makassar Ditjen Perhubungan Laut, sejumlah 50 orang dan seluruhnya menjadi responden dengan menggunakan model analisis regresi liniear berganda.

Hasil penelitian ini menunjukkan bahwa semua variable, yakni factor gaya kepemimpinan direktif, konsultasi, partisipasi dan delegasi memiliki pengaruh yang positif dan signifikan secara simultan terhadap kinerja pegawai pada Kantor Distrik Navigasi Kelas I Makassar Ditjen Perhubungan Laut. Sedang secara parisial ditemukan bahwa faktor gaya kepemimpinan delegasi yang memiliki pengaruh tidak signifikan terhadap kinerja pegawai pada Kantor Distrik Navigasi Kelas I Makassar Ditjen Perhubungan Laut. Berdasarkan hasil penelitian tersebut, penulis menyarankan agar pada Kantor Distrik Navigasi Kelas I Makassar Ditjen Perhubungan Laut dapat lebih memperhatikan factor yang dapat mendorong kinerja seperti pemberian kebebasan berkreasi dan motivasi agar dapat lebih merangsang pegawai untuk bekerja lebih baik lagi.
\end{abstract}

Kata Kunci: Direktif, Konsultasi, Partisipasi dan Delegasi

\section{Abstract}

This study aimed to identify and analyze the influence factors directive leadership style, consultation, participation and delegation affect the performance of employees in Class I Navigation District Office Directorate General of Sea Transportation Makassar. Which serve as a target population of this study are parties related to the performance of Class I Nàvigation District 'Office Directorate General of Sea Transportation Makassar, some 50 people and all the respondents using multiple linear regression analysis model.

The results of this study indicate that all variables, namely factor directive leadership style, consultation, participation and delegation has a positive and significant influence on the performance of employees simultaneously on Class I Navigation District Office Directorate General of Sea Transportation Makassar. In Partial found that the factor of leadership style that delegates have no significant influence on the performance of employees in Class I Navigation District Office Directorate General of Sea Transportation Makassar. Based on these findings, the authors suggest that the Class I Navigation.District Office Director General of Sea Transportation Makassar to pay more attention to factors that can push the performance such as the provision of creative freedom and motivation to better stimulate employees to work better.

Keywords: Directive,consultative,partisipative and delegative

\section{PENDAHULUAN}

Para pegawai membentuk suatu persepsi subyektif keseluruhan mengenai organisasi berdasarkan pada faktor-faktor seperti resiko, tekanan pada tim, dan dukungan orang. Fungsi 
pemimpin dalam kelompok yaitu agar kelompok yang dipimpinnya dapat berjalan efektif, maka pemimpin harus melaksanakan dua fungsi utama yaitu fungsi yang berhubungan dengan tugas menyangkut pemberian penyelesaian suatu masalah, informasi dan pendapat. Dan fungsi yang berhubungan dengan pemeliharaan kelompok menyangkut sesuatu yang dapat membantu kelompok dapat berjalan lebih lancar, persetujuan dengan kelompok lain dan penengahan perbedaan pendapat, (Handoko, 2003: 299). Fenomena di lingkungan Kantor Distrik Navigasi Kelas I Makassar Ditjen Perhubungan Laut menunjukkan bahwa kinerja pegawai dalam melaksanakan tugas dan tanggung jawabnya belum sesuai dengan yang diharapkan. Sebagian pegawai belum mampu melaksanakan tugas tugasnya. Fenomena tersebut diyakini bahwa salah satu penyebabnya adalah faktor perilaku kepemimpinan yang dikembangkan oleh para pemimpin dalam organisasi tersebut. Namun penulis melihat bahwa fenomena tersebut cenderung disebabkan oleh tipe dan gaya kepemimpinan yang diterapkan dalam instansi tersebut.

Simamora (2000 : 4) mengemukakan bahwa manajemen sumber daya manusia adalah pendayagunaan, pengembangan, penilaian, pemberian balas jasa, dan pengelolaan individu anggota organisasi atau kelompok karyawan. Pengertian sumber daya manusia menurut Hariandja (2002 : 2) adalah perencanaan, pengorganisasian, pengarahan, dan pengawasan kegiatankegiatan pengadaan, pengembangan, pemberian kompensasi, pengintegrasian, pemeliharaan, dan pelepasan sumber daya manusia agar tercapai tujuan organisasi dan masyarakat.

Sule dan Saefullah (2004: 13) mengemukakan bahwa manajemen sumber daya manusia adalah penerapan manajemen berdasarkan fungsinya untuk memperoleh sumber daya manusia yang terbaik bagi bisnis yang kita jalankan dan bagaimana sumber daya manusia yang terbaik tersebut dapat dipelihara dan tetap bekerja bersama kita dengan kualitas pekerjaan yang senantiasa konstan ataupun bertambah. Sedangkan Martoyo (2010 : 3) mengemukakan pengertian manajemen sumber daya manusia adalah bekerja dengan orang-orang untuk menentukan, menginterprestasikan dan mencapai tujuan-tujuan organisasi dengan pelaksanaan fungsi-fungsi perencanaan (planning), pengorganisasian, penyusunan personalia atau kepegawaian (staffing), pengarahan dan kepemimpinan (leading) dan pengawasan (controlling).

Irianto ( 2001 : 3 ) bahwa manajemen sumber daya manusia merupakan pengakuan tentang pentingnya tenaga kerja organisasi sebagai sumber daya manusia yang sangat penting dalam memberi kontribusi bagi tujuan-tujuan organisasi, dan penggunaan beberapa fungsi dan kegiatan untuk memastikan bahwa sumber daya manusia tersebut digunakan secara efektif dan bagi kepentingan individu, organisasi dan masyarakat. Hasibuan (2001 : 11) yang berpendapat tentang manajemen sumber daya manusia adalah manajemen sumber daya manusia adalah perencanaan, pengorganisasian, pengarahan dan pengendalian dari pengadaan, pengembangan, kompensasi, pengintegrasian, pemeliharan, dan pemberhentian karyawan, dengan maksud terwujudnya tujuan organisasi, individu, karyawan dan masyarakat.]

\section{Tujuan Penelitian}

1. Untuk mengetahui dan menganalisis pengaruh perilaku kepemimpinan terdiri direktif, konsultasi, partisipasi dan delegasi terhadap kinerja pegawai.

2. Untuk mengetahui dan menganalisis gaya kepemimpinan mana yang 
paling dominan pengaruhnya terhadap kinerja pegawai.

\section{METODE PENELITIAN}

Analisis Deskriptif

Data yang sifatnya berupa dokumen-dokumen dari kantor Distrik Navigasi Kelas I Makassar Ditjen Perhubungan Laut.

\section{Analisis Regresi Berganda}

Adapun data yang diperoleh dari pendekatan empiris dianalisis secara kuantitatif dengan menggunakan teknik pengujian uji multiple regression (regresi berganda) Penggunaan model uji multiple regression, akan membantu untuk melakukan identifikasi setiap variasi independen yang diteliti, sehingga tampak variabel mana dari variabel bebas yang sangat berpengaruh terhadap dependen variabel, baik secara parsial maupun secara serempak. Adapun prosedur analisis data dalam penelitian menggunakan analisis regresi linier berganda dengan menggunakan uji statistik baik uji $\mathrm{F}$ maupun uji $\mathrm{t}$ dengan formulasi sebagai berikut :

$$
\begin{aligned}
\mathrm{Y}= & \mathrm{b} 0+\mathrm{b} 1 \mathrm{X} 1+\mathrm{b} 2 \mathrm{X} 2+\mathrm{b} 3 \mathrm{X} 3 \\
& +\mathrm{b} 4 \mathrm{X} 4+\mathrm{ei}
\end{aligned}
$$

\section{HASIL PENELITIAN}

Populasi yang dijadikan sebagai target penelitian adalah pihak-pihak yang terkait dengan kinerja pegawai kantor Distrik Navigasi Kelas I Makassar Ditjen Perhubungan Laut. sejumlah 50 0rang, Dengan jumlah populasi yang tidak terlalu banyak maka peneliti menggunakan metode sensus.

Data yang diperoleh dalam penelitian ini, diseleksi berdasarkan validitasnya dan selanjutnya dianalisis secara kualitatif dan kuantitatif. Adapun data yang diperoleh dari pendekatan empiris dianalisis secara kuantitatif dengan menggunakan teknik pengujian uji multiple regression (regresi berganda)

Penggunaan model uji multiple regression, akan membantu untuk melakukan identifikasi setiap variasi independen yang diteliti, sehingga tampak variabel mana dari variabel bebas yang sangat berpengaruh terhadap dependen variabel, baik secara parsial maupun secara serempak. Adapun prosedur analisis data dalam penelitian menggunakan analisis regresi linier berganda dengan menggunakan uji statistik baik uji $\mathrm{F}$ maupun uji $\mathrm{t}$ dengan formulasi sebagai berikut :

$$
\begin{aligned}
\mathrm{Y}= & \mathrm{b} 0+\mathrm{b} 1 \mathrm{X} 1+\mathrm{b} 2 \mathrm{X} 2+\mathrm{b} 3 \mathrm{X} 3+ \\
& \mathrm{b} 4 \mathrm{X} 4+\mathrm{ei}
\end{aligned}
$$

Dimana :

$\mathrm{Y}=$ Kinerja Karyawan

$\mathrm{X} 1=$ Perilaku kepemimpinan direktif

$\mathrm{X} 2=$ Perilaku kepemimpinan konsultasi

$\mathrm{X} 3$ = Perilaku kepemimpinan partisipasi

$\mathrm{X} 4=$ Perilaku kepemimpinan delegasi

$\mathrm{b} 0=$ Konstanta

b1, b2, b3, b4 adalah koefisien regresi.

ei $=$ Faktor kesalahan

\section{Uji F}

Untuk melakukan pengujian terhadap hipotesis pertama, dilakukan uji F, yakni uji Kirelatif, hal ini dimaksudkan untuk mengetahui variabel prestasi kerja karyawan. Uji bermakna jika $\mathrm{F}$ - hitung $>\mathrm{F}$ - tabel dengan tingkat kepercayaan $95 \%$ atau $\mathrm{P}<0,05$, dengan demikian hasilnya adalah tolak $\mathrm{H}_{\mathrm{O}}$ dan terima $\mathrm{Ha}$. Sebaliknya jika $\mathrm{P}>0,05$ maka terima $\mathrm{H}_{\mathrm{O}}$ dan tolak $\mathrm{Ha}$. Uji $\mathrm{F}$ ini dilakukan untuk melihat pengaruh variabelvariabel independen secara keseluruhan terhadap variabel dependen.

Uji T

Uji $\mathrm{t}$ ini dilaksanakan untuk melihat signifikasi dari pengaruh independen secara individu terhadap variabel dependen dengan menganggap variabel 
lain bersifat konstan. Uji ini dilaksanakan dengan membandingkan thitung dengan t-tabel. Disamping dengan cara tersebut, diadakan pula penggabungan beberapa independent variabel dengan kelompok tertentu, yang selanjutya diteliti bagaimana pengaruh variabel-variabel bebas terhadap dependent variabel, sehingga akan nampak yang paling mempunyai pengaruh dan lebih signifikan.

\section{Analisis yang dilakukan}

Berdasarkan tujuan penelitian ini yakni untuk mengetahui dan menganalisis pengaruh motivasi kerja, kemampuan dan pengalaman kerja pegawai terhadap kinerja pegawai, setelah dilakukan pengujian hipotesis penelitian ini, maka ketiga variabel bebas yakni: direktif (X1), konsultasi (X2), partisipasi (X3) dan delegasi (X4) berpengaruh positif dan signifikan terhadap kinerja pegawai.

Penelitian ini secara serentak atau bersama-sama keempat variabel bebas terhadap variable terikat yang menunjukkan pengaruh positif dan singnifikan yang dibuktikan dengan besarnya kontribusi $\left(\mathrm{R}^{2}\right)=0,550$ atau $55 \%$.Artinya kinerja pegawai dapat diprediksikan bahwa untuk meningkatkan kinerja pegawai perlu mennggunakan keempat variabel bebas tersebut. Sedang adanya sisa $45 \%$ menunjukkan bahwa masih perlu mencari variabel yang belum dapat teridentifikasi dalam penelitian ini, sehingga bagi para peneliti selanjutnya harus menelusuri lebih mendalam sehingga ditemukan variabel yang dapat memperbesar pengaruh terhadap peningkatan kinerja pegawai tersebut.

Di samping, memperlihatkan temuan secara serentak atau simultan keempat variabel tersebut, maka secara parsial keempat variabel bebas juga perlu dibahas terhadap variabel terikatnya. Untuk mengetahui dan menganalisis secara parsial pengaruh tersebut, maka berikut ini akan diuraikan satu persatu:

\section{Gaya Kepemimpinan direktif terhadap Kinerja Karywan}

Hasil analisis penelitian ini membuktikan bahwa gaya kepemimpinan direktif yang dimiliki oleh pegawai berpengaruh positif dan signifikan terhadap kinerja pegawai yang dapat dibuktikan dengan besaran nilai sumbangannya melalui nilai kontribusi $(X 1)=0,273$ atau $27,30 \%$ dan juga dapat diperlihatkan melalui hasil signifikansinya yakni thitung $=4,515$ dengan probabilitas $=0,000<0,05$, menunjukkan bahwa jika gaya kepemimpinan direktif dapat ditingkatkan, maka akan dapat meningkatkan kinerja pegawai. Hasil pengujian hipotesis ini juga dapat didukung oleh hasil analisis deskriptif tanggapan dari masing-masing pegawai yaitu terdapat 47 orang atau 94\% responden yang mengatakan bahwa gaya direktif yang dimiliki oleh pegawai dapat dikategorikan sesuai hingga pada kategori yang sangat sesuai dalam melaksanakan tugas pokok dan fungsinya. Gaya dasar kepemimpinan dapat memberikan gambaran bahwa tipe kepemimpinan seseorang tidak hanya ditentukan dari pihak pemimpin itu sendiri, melainkan juga harus ditetapkan dari pihak bawahan atau yang dipimpin. Oleh karena itu, perilaku pemimpin dalam proses pengambilan keputusan dan pemecahan masalah, tipe sorang pemimpin dapat diidentifikasi sebagai bentuk- bentuk proses pemecahan masalah dan pengambilan keputusan.

\section{Gaya Kepemimpinan Konsultasi Terhadap Kinerja pegawai}

Hasil analisis penelitian ini membuktikan bahwa gaya kepemimpinan konsultasi yang dimiliki oleh pegawai berpengaruh positif dan signifikan terhadap kinerja pegawai yang dapat 
dibuktikan dengan besaran nilai sumbangannya melalui nilai kontribusi $(X 2)=0,185$ atau $18,50 \%$ dan juga dapat diperlihatkan melalui hasil signifikansinya yakni thitung $=3,156$ dengan probabilitas $=0,003<0,05$, menunjukkan bahwa jika gaya kepemimpinan konsultasi dapat ditingkatkan, maka akan dapat meningkatkan kinerja pegawai. Hasil pengujian hipotesis ini juga dapat didukung oleh hasil analisis deskriptif tanggapan dari masing-masing pegawai yaitu terdapat 46 orang atau 92\% responden yang mengatakan bahwa gaya konsultasi yang dimiliki oleh pegawai dapat dikategorikan cukup sesuai hingga pada kategori yang sangat sesuai dalam melaksanakan tugas pokok dan fungsinya. Gaya dasar kepemimpinan dapat memberikan gambaran bahwa tipe kepemimpinan seseorang tidak hanya ditentukan dari pihak pemimpin itu sendiri, melainkan juga harus ditetapkan dari pihak bawahan atau yang dipimpin. Oleh karena itu, perilaku pemimpin dalam proses pengambilan keputusan dan pemecahan masalah, tipe sorang pemimpin dapat diidentifikasi sebagai bentuk-bentuk proses pemecahan masalah dan pengambilan keputusan.

\section{Gaya Kepemimpinan Partisipasi Terhadap Kinerja Pegawai}

Hasil analisis penelitian ini membuktikan bahwa gaya kepemimpinan partsipasi yang dimiliki oleh pegawai berpengaruh positif dan signifikan terhadap kinerja pegawai yang dapat dibuktikan dengan besaran nilai sumbangannya melalui nilai kontribusi $(\mathrm{X} 3)=0,176$ atau $17,60 \%$ dan juga dapat diperlihatkan melalui hasil signifikansinya yakni thitung $=4,432$ dengan probabilitas $=0,000<0,05$, menunjukkan bahwa jika gaya kepemimpinan partisipasi dapat ditingkatkan, maka akan dapat meningkatkan kinerja pegawai. Hasil pengujian hipotesis ini juga dapat didukung oleh hasil analisis deskriptif tanggapan dari masing-masing pegawai yaitu terdapat 49 orang atau $98 \%$ responden yang mengatakan bahwa gaya kepemimpinan partisipasi yang dimiliki oleh pegawai dapat dikategorikan cukup sesuai hingga pada kategori yang sangat sesuai dalam melaksanakan tugas pokok dan fungsinya. Gaya dasar kepemimpinan dapat memberikan gambaran bahwa tipe kepemimpinan seseorang tidak hanya ditentukan dari pihak pemimpin itu sendiri, melainkan juga harus ditetapkan dari pihak bawahan atau yang dipimpin. Oleh karena itu, perilaku pemimpin dalam proses pengambilan keputusan dan pemecahan masalah, tipe sorang pemimpin dapat diidentifikasi sebagai bentuk-bentuk proses pemecahan masalah dan pengambilan keputusan.

\section{Gaya Kepemimpinan Delegasi terhadap Kinerja Pegawai}

Hasil analisis penelitian ini membuktikan bahwa gaya kepemimpinan partsipasi yang dimiliki oleh pegawai berpengaruh positif dan signifikan terhadap kinerja pegawai yang dapat dibuktikan dengan besaran nilai sumbangannya melalui nilai kontribusi $(\mathrm{X} 4)=0,155$ atau $15,50 \%$ dan juga dapat diperlihatkan melalui hasil signifikansinya yakni thitung $=1,428$ dengan probabilitas $=0,160<0,05$, menunjukkan bahwa gaya kepemimpinan partisipasi tidak dapat mendukung kinerja pegawai.Gaya dasar kepemimpinan dapat memberikan gambaran bahwa tipe kepemimpinan seseorang tidak hanya ditentukan dari pihak pemimpin itu sendiri, melainkan juga harus ditetapkan dari pihak bawahan atau yang dipimpin. Oleh karena itu, perilaku pemimpin dalam proses pengambilan keputusan dan 
pemecahan masalah, tipe sorang pemimpin dapat diidentifikasi sebagai bentuk-bentuk proses pemecahan masalah dan pengambilan keputusan.

Secara keseluruhan gaya kepemimpinan pada Kantor Distrik Navigasi Kelas I Makassar Ditjen Perhubungan Laut yang terdiri dari gaya direktif, konsultasi, partisipasti, dan delegasi memberikan pengaruh simultan terhadap kinerja karyawan. Secara parsial dari masing-masing variabel bebas yang diteliti memberikan pengaruh terhadap kinerja pegawai Kantor Distrik Kelas I Makassar Ditjen Perhubungan Laut :

a. Gaya kepemimpinan direktif berpengaruh terhadap kinerja karyawan yang ditentukan oleh gaya pimpinan dalam berkomunikasi satu arah, memberikan batasan apa,kapan,dimana dan bagaimana tugas dilaksanakan, pemecahan dan pengambilan keputusan oleh pimpinan, pelaksanaan pekerjaan diawasi dengan ketat.

b. Gaya kepemimpinan konsultasi berpengaruh terhadap kinerja karyawan yang ditentukan oleh gaya pimpinan dalam memberi peluang untuk pengambilan keputusan dan menasehati, memberikan kesempatan kepada bawahan dalam berkreasi.

c. Gaya kepemimpinan partisipatif berpengaruh terhadap kinerja karyawan yang ditentukan oleh gaya pimpinan selalu mendukung para karyawan, dan mau menerima kritik,saran, pendapat serta terbuka dalam melakukan komunikasi dua arah .

d. Gaya kepemimpinan delegasi berpengaruh tidak signifikan terhadap kinerja karyawan yang ditentukan oleh gaya pimpinan dalam memberikan pengarahan dan dukungan namun memberikan kepercayaan kepada pegawai serta sedikit memberikan kepercayaan kepada karyawan.

\section{KESIMPULAN}

Hasil penelitian menunjukkan bahwa variabel gaya kepemimpinan direktif yang paling dominan berpengaruh terhadap kinerja pegawai Kantor Distrik Navigasi Kelas I Makassar Ditjen Perhubungan Laut.

\section{DAFTAR PUSTAKA}

Handoko T. Hani, 2009. Manajemen Personalia dan Sumber Daya Manusia, Edisi ke-2, BPFE : Yogjakarta.

Simamora, Henry, 2000, Manajemen Sumber Daya Manusia, cetakan pertama edisi ke dua, Penerbit : YKPN, Yogyakarta.

Hariandja, Marihot Tua Efendi, 2009, Manajemen Sumber Daya Manusia, Penerbit : Gramedia Widiasarana Indonesia, Jakarta.

Sule, Ernie Tisnawati dan Kurniawan Saefullah, 2004, Pengantar Manajemen, edisi pertama, cetakan pertama, Penerbit : Prenada Media, Jakarta.

Martoyo, Susilo, 2010, Manajemen Sumber Daya Manusia, edisi keempat, cetakan pertama, Penerbit : BPFE, Yokyakarta.

Irianto Yusuf, 2010, Tema-Tema Pokok Manajemen Sumber Daya Manusia, cetakan pertama, Penerbit : Insan Cendikia, Surabaya.

Hasibuan, Malayu.,2009. Manajemen Sumber Daya Manusia, Bumi Aksara : Jakarta. 